\title{
MSI-testing in hereditary non-polyposis colorectal carcinoma (HNPCC) ${ }^{1}$
}

\author{
Annegret Müller ${ }^{\mathrm{a}}$, Tina Bocker Edmonston ${ }^{\mathrm{b}}$, Wolfgang Dietmaier ${ }^{\mathrm{c}}$, Reinhard Büttner ${ }^{\mathrm{d}}$, \\ Richard Fishel ${ }^{\mathrm{e}}$ and Josef Rüschoff ${ }^{\mathrm{f}, *}$ \\ ${ }^{a}$ Department of General Surgery, University of Göttingen, Göttingen, Germany \\ ${ }^{\mathrm{b}}$ Department of Pathology, Thomas Jefferson University, Philadelphia, PA, USA \\ ${ }^{\mathrm{c}}$ Department of Pathology, University of Regensburg, Germany \\ ${ }^{\mathrm{d}}$ Department of Pathology, University of Bonn, Germany \\ ${ }^{\mathrm{e}}$ Kimmel Cancer Institute, Thomas Jefferson University, Philadelphia, PA, USA \\ ${ }^{\mathrm{f}}$ Department of Pathology, Klinikum Kassel, Kassel, Germany
}

\begin{abstract}
Genomic instability at simple repeated sequences, termed microsatellite instability (MSI), plays an important role in the analysis of sporadic and hereditary colon cancers. In hereditary non-polyposis colorectal cancer syndrome (HNPCC) more than $90 \%$ of cases show MSI, whereas only $10-15 \%$ of sporadic colorectal cancers do so. Thus, microsatellite analysis is commonly used as the first diagnostic screening test for HNPCC. In 1997, an international collaborative workshop sponsored by the National Cancer Institute (NCI) proposed a set of guidelines for MSI-testing to improve reliability and reproducibility of the analysis as well to allow comparisons between different studies and different laboratories.

In this review we assess the value of current protocols forMSI-testing and discuss some diagnostic pitfalls.

Our findings support continued use of the MSI marker panel recommended in 1997. Additionally, MSI-testing should be improved by use of microdissection, which helps to identify additional patients with MSI due to enrichment of tumor cells and therefore increased sensitivity. In our view, immunohistochemical staining for mismatch repair protein expression is not a substitute for MSI-analysis but complements MSI screening and helps direct further testing.

In summary, MSI-analysis is a highly sensitive and reliable screening method for HNPCC, that requires a well-equipped laboratory as well as an experienced pathologist. Integration of family history and histo-pathological features is also critical.
\end{abstract}

Keywords: MSI-analysis, laser microdissection, immunohistochemistry

\section{Introduction}

During normal DNA replication, replication errors occur frequently and other types of DNA damage can be caused by exogenous factors. However, in all organisms a multitude of repair mechanisms have evolved

\footnotetext{
${ }^{1}$ Supported by the German Cancer Aid (Deutsche Krebshilfe) within the German Consortium on Hereditary Colon Cancer to R.B. and J.R (Grant 70-240I-Rü II). ${ }^{2}$

${ }^{2}$ Informations about the Consortium: www.hnpcc.de.

*Corresponding author: Prof. Dr. Josef Rüschoff, Intsitute of Pathology, Klinikum Kassel, Moenchebergstr. 41-43, D-34125 Kassel, Germany. Tel.: +49 561980 4001; Fax: +49 561980 6983; E-mail: ruesch@klinikum-kassel.de.
}

that maintain the stability of genomes through succeeding generations of cells. One of these mechanisms is DNA mismatch repair (MMR) that detects single base mismatches as well as insertion/deletion loops occurring during normal DNA replication and directs the correction of the replication error. This repair mechanism is highly conserved in eukaryotes and prokaryotes [54, 55].

A lack of appropriate repair results in the so-called "Mutator Phenotype", which leads to the accumulation of mutations, increased mutation rates, and ultimately genomic instability (Fig. 1). (The term "Mutator Phenotype" [47] reflects the fact that the DNA mismatch repair (MMR) system itself is altered leading to a global 


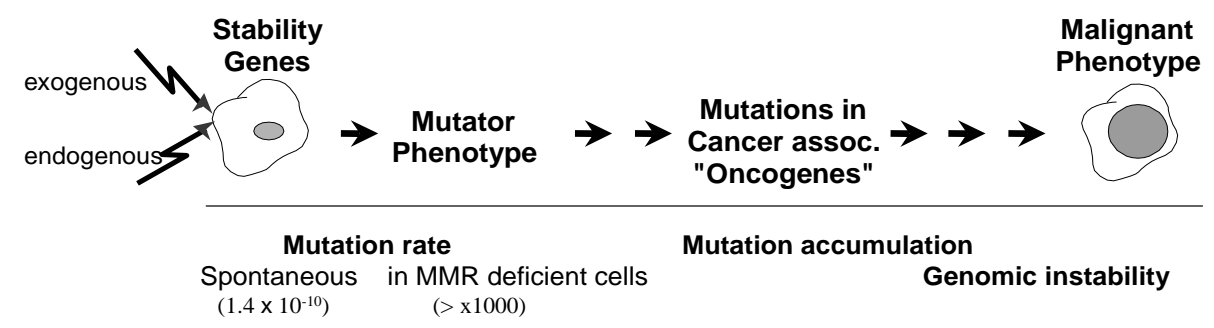

Fig. 1. Mutator model as a concept of molecular carcinogenesis in MMR deficient cells (acc. to [47]).

genomic instability).

Nucleotide mismatches arise in double stranded DNA in at least three different ways: physical or chemical damage, genetic recombination between strands that lack perfect homology, as well as insertion or deletion of nucleotides during the reannealing process in replication that is thought to be caused by slippage of the DNA strands. Loss of MMR itself leads to the persistence of these mismatches that are then carried through subsequent cell divisions and thus lead to an increase in mutation rates. Microsatellite instability (MSI) is a hallmark of MMR deficiency since microsatellites are particularly prone for replication errors [81].

Microsatellites are distributed throughout the human genome, and consist of short tandem repeats of simple di-, tri-, or tetra-nucleotide motifs. In most cases microsatellites are located in non-coding regions and show high inter-individual polymorphism, which can be used for haplotyping [91]. However, in one individual the microsatellite pattern is identical in any given nucleated cell of the body. Microsatellite analysis has been used in the analysis of certain inherited diseases and in some types of cancer. Expansions of tri-nucleotide repeats were found in Huntington's disease [82] and fragile X syndrome [42], Myotonic Dystrophy [52], spinocerebellar ataxia [59], Machado-Joseph disease [16], and Friedreich's ataxia [18]. In cancer genetics, microsatellite analysis is useful for identifying losses of heterozygosity $(\mathrm{LOH})$ and for the detection of somatic microsatellite instability as a result of MMR deficiency $[1,2,27,80,83]$.

Although the exact molecular mechanism leading from the MMR deficiency to cancer is not fully understood, the analysis of length alterations of simple repeated (microsatellite) sequences provides a useful screening technique to identify tumors with underlying MMR defects $[63,64]$.

\section{MSI in HNPCC}

HNPCC is the most common form of hereditary cancer, and accounts for $2-4 \%$ of the total colorectal cancer burden $[9,50,51,60]$. Since there are no characteristic clinical features that are specific for HNPCC, the diagnosis is based on family history (Amsterdam or Bethesda criteria) and is confirmed by the detection of a germline mutation in one of the MMR genes [10,20, $51,65,68,70,85,86]$.

The first observation that distinguished a subgroup of colorectal cancers (HNPCC or Lynch syndrome) from sporadic colorectal cancers was the observation of length alterations in short repetitive sequences of the tumor DNA compared to DNA from normal tissue of the same patient. This was initially termed "replication error" (RER) which was later modified to "microsatellite instability" (MSI) in the first microsatellite consensus conference [1,2,10,34,64].

High frequency of microsatellite instability in $\mathrm{HN}-$ PCC suggested that there might be a mutation in the human homologue of MMR-genes previously described in bacteria and yeast. In 1993 Fishel et al. were the first to clone the first human homolog which was called hMSH-2 (MutS homolog) [23]. Up to date, there are seven known human homologs (hMSH2, hMLH1, hPMS2, hPMS1, hMSH6, hMSH3 and hMLH3) and germline mutations of four of these have been implicated in human cancer syndromes (hMLH1, hMSH2, hMSH6, and hPMS2). In addition, hMLH3 and hPMS1 mutations have been detected, however, it is still controversial whether germline mutations of hMLH3 and hPMS1 play a role $[13,23,40,44,57,58,61,62,69,93]$.

MSI-H is identified in more than $90 \%$ of the tumors of patients fulfilling the diagnostic criteria of HNPCC and in only $10-15 \%$ of different types of sporadic tumors including gastric, endometrial and upper urinary tract carcinomas $[26,45,46,64,85]$. The occurrence of MSI-H in tumors other than colorectal cancer suggest that the pathogenesis of these tumors might be similar to HNPCC [45]. 
Table 1

Consensus microsatellite primer panel suggested by the International Collaborative Group on Hereditary Colorectal Cancer (ICG-HNPCC) [10]

\begin{tabular}{llll}
\hline BAT 26 & $2 \mathrm{p}$ & TGA CTA CTT TTG ACT TCA GCC & (Papadopoulos [61]) \\
\hline \multirow{2}{*}{ BAT 40 } & $1 \mathrm{p} 13.1$ & $\begin{array}{l}\text { AAC CAT TCA ACA TTT TTA ACC G } \\
\text { ATT AAC TTC CTA CAC CAC AAC } \\
\text { GTA GAG CAA GAC CAC CTT G }\end{array}$ & (Liu et al. [46]) \\
APC(D5S346) & $5 \mathrm{q} 21 / 22$ & $\begin{array}{l}\text { ACT CAC TCT AGT GAT AAA TCG } \\
\text { AGC AGA TAA GAC AGT ATT ACT AGT T }\end{array}$ & (Spirio et al. [79]) \\
Mfd15CA(D17S250) & $17 \mathrm{q} 11.2-\mathrm{q} 12$ & $\begin{array}{l}\text { GGA AGA ATC AAA TAG ACA AT } \\
\text { GCT GGC CAT ATA TAT ATT TAA ACC }\end{array}$ & (Weber et al. [89,90]) \\
D2S123 & $2 \mathrm{p} 16$ & AAA CAG GAT GCC TGC CTT TA & (Weissenbach et al. [90]) \\
& & &
\end{tabular}

Current recommendations classify MSI-H tumors from patients fulfilling the Bethesda Guidelines as very likely being HNPCC $[70,71,83,84]$. It is important to keep in mind that $80 \%$ of all colorectal cancer (including sporadic cancers) with MSI-H show loss of expression of hMLH1 protein $[17,19,31,76]$ by immunohistochemistry. In many cases loss of hMLH1 expression is not caused by a mutation, but is due to methylation of $5^{\circ} \mathrm{CpG}$ islands in the hMLH1 promotor thereby inactivating the transcription of the gene [17]. In these cases the most important factor is the age of the patient. Under an age of 65 hypermethylation of the promotor resulting in MSI-H is very rare and MSI-H is highly suspicious for HNPCC syndrome. Other clinical, pathological and molecular features may support the interpretation [31,76]. In contrast, a loss of hMSH2 protein expression is always suspicious of HNPCC.

\section{MSI and carcinogenesis}

As mentioned earlier, MSI-H can be found in about $15 \%$ of all colorectal cancers [84]. These tumors have several clinical and pathological features in common i.e. frequent location within the proximal colon, and a mucinous/solid or cribriform histologic growth pattern, commonly associated with poor differentiation $[5$, $35,36,72]$. However, despite the seemingly poor differentiation the prognosis for these patients appears to be better overall $[22,24,25,41,72]$. The DNA content is diploid in most cases and the p53 tumor suppressor gene is expressed in its wild-type form [8,24,41]. Figure 2 illustrates the typical features of MSI tumors.

However, several studies demonstrate, that sporadic MSI-H tumors and tumors from HNPCC patients show a slightly different molecular pathogenesis.

A germline mutation in one of the MMR genes is found in the majority of the HNPCC patients, whereas in sporadic MSI-H tumors a germline mutation could only be detected in about $10 \%$. These might represent de novo mutations or there is reduced penetrance in the parents. Truly sporadic MMR deficient cancers without germline mutations are caused by two somatic events inactivating a MMR gene (Fig. 3). This could either occur through LOH or other somatic genetic events or through epigenetic inactivation of MLH1 caused by hypermethylation of its promoter [87].

Although the exact molecular mechanism leading from the mutator phenotype to malignant transformation in HNPCC patients is not completely understood, it is generally assumed that tumors which arise from MMR defects are the result of the increased spontaneous mutation rate. A number of important genes implicated in immune surveillance as well as in growth and apoptosis regulation harbor microsatellites, which, if disrupted by microsatellite instability, will lead to cancer. Important target genes that have been identified in HNPCC include proliferation and apoptosis genes like TGF-beta-receptor II, BAX, immune surveillance genes such beta- 2 microglobulin, DNA repair genes like hMSH3 and hMSH6 and cell cycle regulator genes like E2F4 and BLM (Fig. 4) [3,11,15,32,39,53,66,78, 76].

MSI as a prognostic marker depends on the location of the tumor. In the colon, patients with MMR deficient carcinomas survived longer than patients with MMR proficient sporadic carcinomas of the same stage. However, in gastric and pancreatic carcinomas microsatellite instability is correlated with a worse prognosis [28, 56].

\section{Diagnostic approach for assessment of MMR deficient tumors}

A diagnostic "stepladder" is recommended for $\mathrm{HN}$ PCC. Based on the knowledge that over $90 \%$ of tumors from HNPCC patients harbor an MSI-H phenotype, an 
Table 2

Correlation of MSI results with immunohistochemical staining for hMLH1, hMSH2 and hMSH6

\begin{tabular}{|c|c|c|c|c|c|c|c|c|}
\hline \multirow[t]{2}{*}{$\mathrm{C}$} & \multicolumn{2}{|c|}{ MLH1 - } & \multicolumn{2}{|c|}{ MSH2 - } & \multicolumn{2}{|c|}{ MSH6 - } & \multicolumn{2}{|c|}{ MSH2-/MSH6- } \\
\hline & abs & $(\%)$ & abs & $(\%)$ & abs & (\%) & abs & $(\%)$ \\
\hline MSI-H & 66 & 100,0 & 25 & 100,0 & 8 & 100,0 & 10 & 100,0 \\
\hline BAT25 & 60 & 90,9 & 23 & 92,0 & 8 & 100,0 & 10 & 100,0 \\
\hline BAT26 & 64 & 97,0 & 24 & 96,0 & 6 & 75,0 & 10 & 100,0 \\
\hline APC & 49 & 74,2 & 16 & 64,0 & 4 & 50,0 & 10 & 100,0 \\
\hline Mfd 15 & 39 & 59,1 & 13 & 52,0 & 4 & 50,0 & 7 & 70,0 \\
\hline D2S123 & 49 & 60,6 & 14 & 56,0 & 2 & 25,0 & 4 & 40,0 \\
\hline
\end{tabular}

\begin{tabular}{|c|c|c|c|}
\hline & $\mathbf{N} \quad \mathbf{T}$ & $\mathbf{N} \quad \mathbf{T}$ & $\mathbf{N} \quad \mathbf{T}$ \\
\hline \multirow[t]{2}{*}{\begin{tabular}{|l|}
$\begin{array}{l}\text { Molecular } \\
\text { genetics }\end{array}$ \\
\end{tabular}} & $\overline{\bar{\equiv}} \overline{\bar{\equiv}}$ & $\overline{=}=$ & $\overline{\overline{ }}=$ \\
\hline & MSS & $\mathrm{LOH}$ & MSI \\
\hline \multicolumn{4}{|l|}{ Pathology } \\
\hline O Localisation & \multicolumn{2}{|c|}{ distal } & proximal \\
\hline Histology & \multicolumn{2}{|c|}{ glandular } & $\begin{array}{l}\text { mucinous,solid } \\
\text { cribriform }\end{array}$ \\
\hline $\begin{array}{l}\text { O peritumoral } \\
\text { Inflammation }\end{array}$ & \multicolumn{2}{|r|}{$\downarrow$} & $\uparrow$ \\
\hline Ploidy & \multicolumn{2}{|c|}{$\begin{array}{l}\text { aneuploid } \\
(\mathrm{CGH}+)\end{array}$} & $\begin{array}{l}\text { diploid } \\
\text { (CGH - ) }\end{array}$ \\
\hline p53 Protein & \multicolumn{2}{|c|}{ positiv } & negativ \\
\hline Proliferation & \multicolumn{2}{|r|}{$\uparrow$} & $\downarrow$ \\
\hline \multicolumn{4}{|l|}{ Clinical implications } \\
\hline O HNPCC / Lynch & \multicolumn{2}{|r|}{ - } & typical \\
\hline Prognosis & \multicolumn{2}{|r|}{$\downarrow$} & $\uparrow$ \\
\hline C Chemoresistency & \multicolumn{2}{|r|}{ - } & 5FU, Cisplatin \\
\hline
\end{tabular}

Fig. 2. Molecular classification of colorectal cancer - clinico-pathological features of tumours revealing MSS/LOH or MSI-H phenotype.

inexpensive prescreen consists of microsatellite analysis of the tumor prior to the search for a germline mutation of one of the MMR genes [4,10,20,38,71]. Since germ-line mutations are found in only $\sim 60 \%$ of the cases that are HNPCC by history and MSI status, MSI is invaluable to identify patients as MMR deficient even if a germline mutation can not be identified with the methods currently available.

Until 1997 it was unclear how many markers and on which chromosomal loci MSI analysis should be performed. Until then, more than hundred markers had been widely used for MSI analysis and occasional instability was found in a vast majority of tumors whenever large numbers of microsatellite markers were used. However, it was unclear how many markers need to be studied and how many of them have to be unstable to sensitively and specifically identify MMR deficient tumors.

To address both issues Dietmaier et al. [20] performed a study to provide clear recommendations. For that purpose 58 colorectal cancers were tested with 31 microsatellite markers. Out of these 58 tested colorectal cancers 15 cases displayed instability in more than $20 \%$ of 31 loci tested (MSI-H), 12 cases displayed instability in less than $10 \%$ of all markers tested (MSI-L) and the rest did not show instability (MSS). The MSI-H category was associated with loss of expression of one of the two MMR proteins hMLH1 and hMSH2 in 14 of 15 cases, whereas the MSI-L and the MSS categories consistently expressed both proteins. The microsatellite markers with the highest sensitivity and specificity for detecting of MSI-H tumors were selected.

Figure 5 summarizes the results of the MSI analysis of the 31 loci that were tested in this study. Based on these data BAT 26, BAT 40 and Mfd 15 (D17S250) are most specific to detect MSI-H tumors, whereas APC (D5S346) and D2S123 are most sensitive, detecting MSI-L and MSI-H tumors.

Using these five microsatellite markers all of the cases diagnosed as MSI-H are detected with an overall percentage of instability of $40 \%$ of the markers. Together with accompanying immunohistochemical ex- 


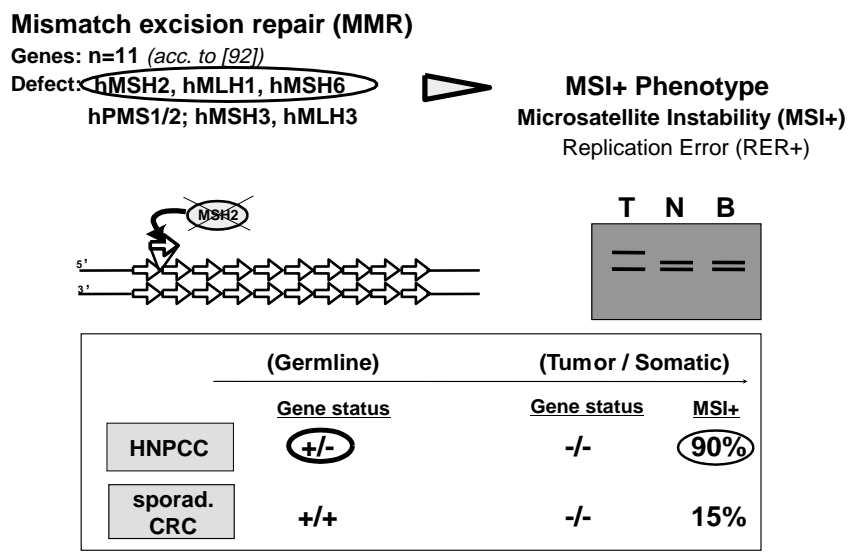

Fig. 3. Molecular pathogenesis of MSI phenotype (main HNPCC causing genes encircled). Gene carrier status in comparison between HNPCC and sporadic colorectal cancer (bottom).

\section{„Target Genes“}
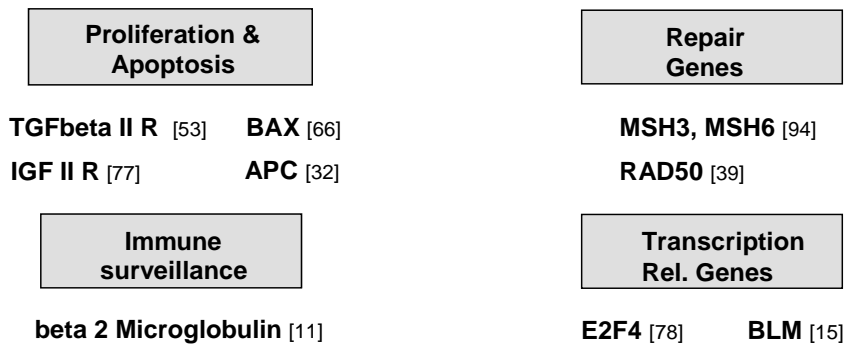

Fig. 4. Major "target genes" containing coding microsatellites that have been found to be affected in MMR deficient tumors and might play a role in the molecular carcinogenesis of MMR deficient neoplasms.

amination of the MMR protein expression, these markers were recommended as the first choice primer panel. In cases where only one of the five markers is found to be unstable the authors suggested to test five additional microsatellite loci.

In addition, the study also demonstrated that mononucleotide markers are more sensitive to detect microsatellite instability than markers with a repeat length of two or more. This might simply be due to the fact that mononucleotid repeats are most frequent microsatellites in the human genome. In addition, mononucleotide repeats might be more prone for polymerase slipping. The panel suggested by Dietmaier et al. [20] was adopted by the International Collaborative Group on Hereditary Colorectal Cancer (ICG-HNPCC), except for BAT 40 which was replaced by BAT 25 [10].

For the purpose of uniform interpretation, tumors with two or more unstable markers were defined as MSI-H, tumors with instability in one marker as MSI-
$\mathrm{L}$ and tumors in which none of the markers revealed instability as MSS. LOHs are not counted as instability and cancers displaying LOH but no MSI are still classified as MSS.

Recently Loukola et al. [49] tested the hypothesis that the analysis of BAT 26 alone is specific and sensitive enough to detect all hMLH1/hMSH2 mutation positive HNPCC patients. The use of BAT 26 would have some advantages, because

1. it has been found to be extremely sensitive in different studies,

2. it is not polymorphic so that the test can be performed without normal matched DNA. Howev$\mathrm{er}$, this is not recommended for patient testing as some ethnic groups show rare polymorphisms,

3. a test based on one marker obliterates the confounding MSI-L category.

A total of 494 unselected colorectal cancers were analyzed with the standard primer panel and compared 


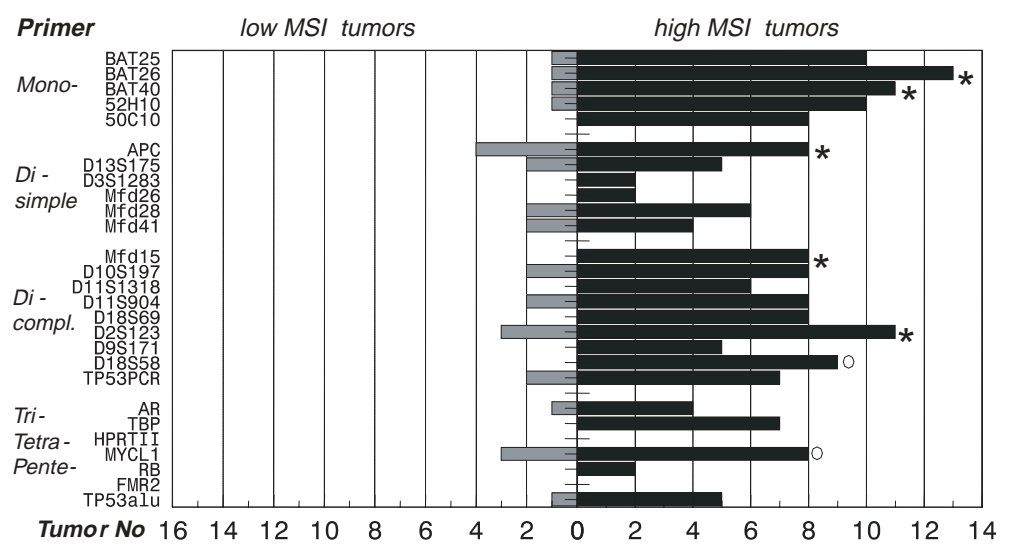

Fig. 5. Sensitivity and specificity of 31 microsatellite markers in the detection of MSI-H tumors (acc. to [20]). Markers originally suggested as most useful for a diagnostic marker panel (see: *).

with the results with BAT 26 alone. In 73 of the 494 cases the final result was MSI-H with the consensus panel as well as with BAT 26 alone. Additionally, two cases read as MSI-H and 20 cases read as MSI-L using the consensus panel had to be downgraded to MSS with BAT 26 alone. Interestingly, in the two cases, which were not classified as MSI-H using BAT 26 alone, a mutation was not found in hMLH1 or hMSH2 gene, whereas the direct genomic sequencing of the hMSH6 gene revealed a missense change in one case, which was reported as pathogenic mutation by Wu et al. [92], but could also represent a rare polymorphism.

The significance of the MSI-L category is still unclear and it may not be a homogeneous group. Therefore, it is tempting to eliminate this poorly defined category that seems to share common clinical features with the MSS group and is clearly different from the MSI$\mathrm{H}$ category of HNPCC-related tumors. Many studies combine MSS and MSI-L in one group. However, MSI-L tumors show a higher frequency of K-ras mutations [12] and a reduced expression of bcl-2 [6]. In addition, cases with underlying hMSH6 mutations might be missed when eliminating the MSI-L category because they have been described as often having low levels of microsatellite instability [92]. The two MSI-H cases in which BAT 26 was found to be stable and that would been have interpretated as MSS, might well be due to hMSH6 mutations. More studies are needed to evaluate the prognostic value of the MSI-L subgroup of colorectal tumors.

At the same time a few tumors might test as unstable with BAT26 alone, resulting in a misclassification as MSI, even there was none in that study. We saw one case of an intramucosal rectal carcinoma in a 66-yearold man without family history where MSI was present in BAT26 but in no other of 10 microsatellite markers. This tumor was positive for immunohistochemical expression of hMSH2 and hMLH1. hMSH6 testing was not performed (T.B.E. and R.F. unpublished observation). False-positive results may lead to over-treatment and unnecessary psychological stress for the individual and the family.

For screening of patients, we therefore still recommend the consensus panel of microsatellite markers, which has been used by multiple centers and has been reconfirmed by a second NCI-sponsored MSI workshop in 2002.

\section{Methods for detecting MSI}

Diagnostic MSI is performed by polymerase chain reaction (PCR) amplification of DNA isolated from microdissected tumor and normal tissue by comparing the length of microsatellite alleles in the same individual.

The steps for MSI-analysis are:

1. Archival paraffin-embedded tissue (tumor and normal), frozen tissue blocks and blood samples from the same patient can be used as templates.

2. Microdissection of tumor and normal areas for each patient (manual microdissection or lasermicrodissection).

3. DNA isolation and purification of DNA.

4. PCR (simplex-PCR, multiplex-PCR, Real-Time PCR [21]).

5. Analysis of PCR-product (Nonradioactive/ Radioactive Labelling [14,74], Automated Sequencer/capillary electrophoresis, Melting Point analysis). 

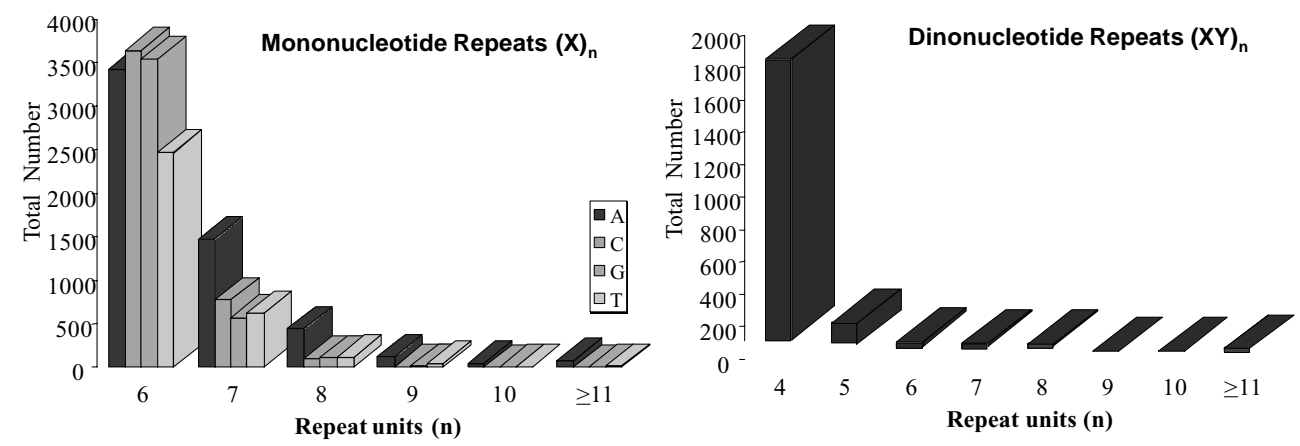

Fig. 6. Frequency of coding microsatellites with different motif length throughout the human genome (J. Gebbert, Inst. of Molecular Pathology, Univ. of Heidelberg, personal communication).

6. Interpretation of normal compared to tumor DNA at different microsatellite loci.

7. Integration of MSI and clinico-pathologic parameters.

In MSI-testing an important potential reason for unexpected results is intralesional heterogeneity. As the tumor evolves, different areas of the tumor may show a different extent of MSI [75]. If there is significant contamination of the tumor with normal cells, be it an inflammatory infiltrate, or areas of necrosis or fibrosis, a MSI-H status might be overlooked. We recommend laser-microdissection for achieving an accurate MSI result rather than the manual microdissection commonly used today. To avoid that the number of cells obtained by using laser-microdisssection falls below a necessary minimum, which might cause other problems (see below) we amplify at least 100 cells. In our hands the optimum number of template cells ranges between $100-300$ cells.

Briefly, sections are mounted onto a polyethylene membrane and attached to a glass slide with rubber cement (Marabuwerke, Tamm, Germany). After staining with hematoxylin, laser-microdissection is carried out e.g. using the Leica DM LMD system. About 100300 epithelial cells from each sample are harvested into microtubes. Cell lysis is performed by dispensing $20 \mu \mathrm{l}$ buffer into each lid. The buffer consists of $8 \mu \mathrm{g}$ proteinase $\mathrm{K}$ ( $4 \mathrm{mg} / \mathrm{ml}$ stock) (Roche, Mannheim, Germany), 0.5\% Tween 20 (Merck, Darmstadt, Germany) and 1x Taq PCR buffer (Roche, Mannheim, Germany). After incubation for 18 hours at $50^{\circ} \mathrm{C}$, proteinase $\mathrm{K}$ is inactivated at $94^{\circ} \mathrm{C}$ for 10 minutes.

PCR analysis can be done by single PCR, multiplex PCR and by real-time PCR. The development of these new techniques allows faster screening which has increasing clinical importance as the treatment of tumors is starting to depend more and more on the molecular profile of the tumors [88], which is demonstrated by a study from Ribic et al. [67]. They demonstrated in a study on 570 colon cancer patients that a fluorouracilbased adjuvant chemotherapy is advantageous for patients with a MSS or MSI-L tumor, but does not improve the prognosis for patients with a MSI-H tumor. However, the latter have a better overall prognosis irrespective of fluorouracil treatment [67]. Chemoprevention with cyclooxygenase inhibitors (e.g., Aspirin) might turn out to be clinically important. It has been reported that COX-inhibitors reversibly suppress microsatellite instability and slows down growth in MMR deficient cell lines [73] and an international collaborative study is currently investigating the effects of non-steroidal antiinflammatory drug prophylaxis in HNPCC patients at risk.

Whereas for single and multiplex PCR DNA electrophoretic fragment analysis has to be done results can be visualized directly in real-time PCR by determination of the melting point which allows assessment of the MSI-status of a DNA sample within one 1 hour. However, currently, a real-time PCR assay is only available for the amplification and melting point analysis of BAT 25 and BAT 26 with all the limitations of such a restriction in microsatellite loci discussed above. Especially, if a sample shows one stable and one unstable marker, an additional MSI analysis has to be done.

For comparison, multiplex-PCR of the first choice primer panel with the HNPCC Microsatellite Instability test (Roche, Mannheim, Germany) and capillary or conventional polyacrylamide electrophoresis allows a result in about 4-12 hours after DNA extraction.

\section{Experiences at our institution and potential pitfalls in MSI analysis}

In our department a prospective unselected series of 580 consecutive cases was analyzed between 7/1998 


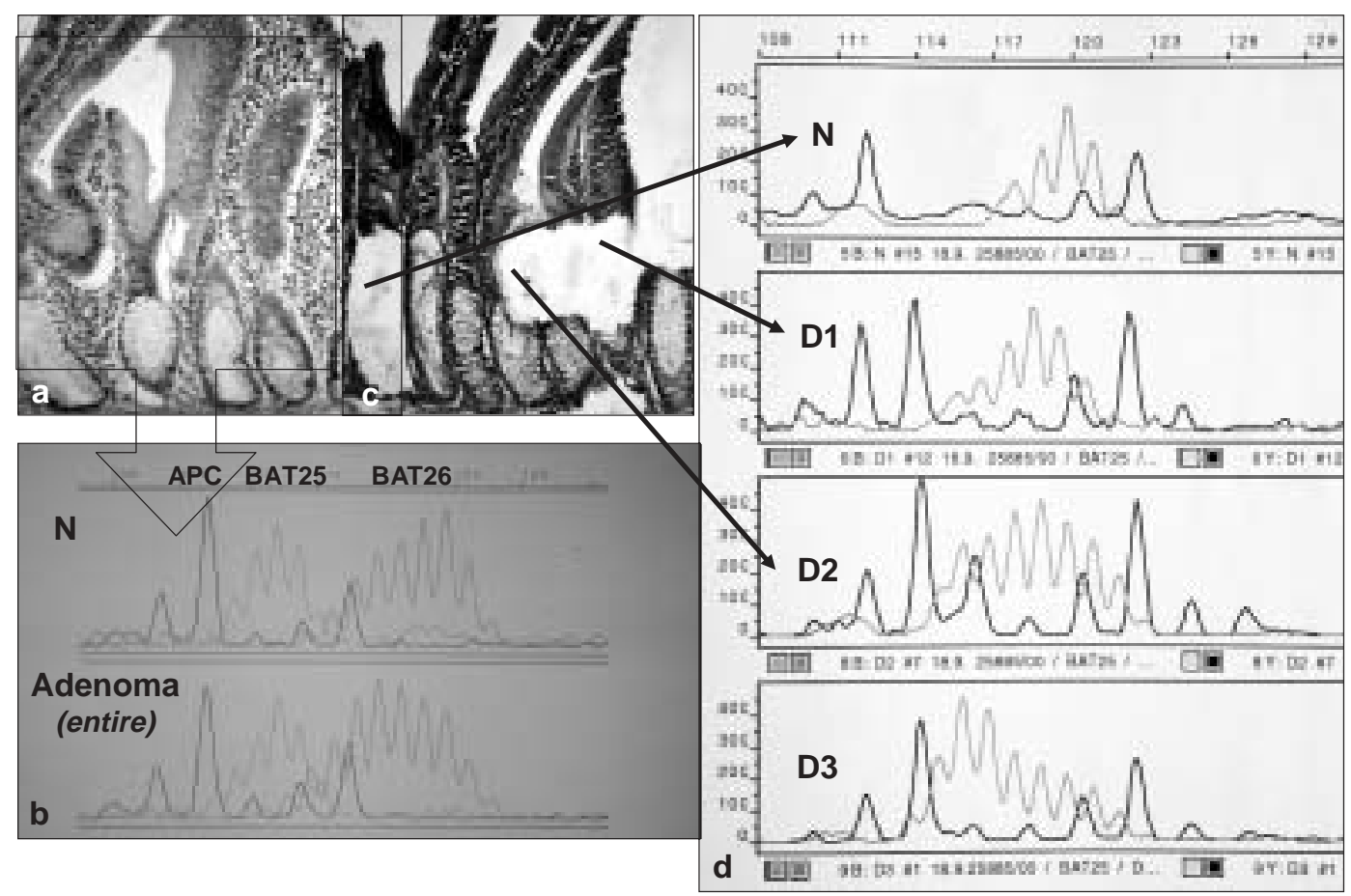

Fig. 7. a-c. Value of laser microdissection for MSI detection in HNPCC associated adenomas. a,b. Whole tissue section analysis reveals no unequivocal shifts at APC (D5S346), BAT25 and BAT26. c,d. Dissection of tumor cells according to the degree of dysplasia, however, discloses the distinct MSI phenotype.

and 11/2002 after obtaining informed consent. Our study was part of a German multicenter study started in 1998 which is funded by the German Krebshilfe (Cancer Aid Program Grant 70-240I-Rü II). MSIanalysis was performed using the HNPCC Microsatellite Instability test (Roche, Mannheim, Germany) on paraffin embedded tissue specimens. 121 (21\%) of these 580 unselected cases were MSI-H and 24 (4\%) were MSI-L. Additionally, immunohistochemical analysis of hMSH2, hMLH1 and hMSH6 was done on all cases that displayed MSI-H. 109 (90\%) of the tumors with MSI-H revealed loss of MMR protein expression. 25 cases (21\% of 121 MSI-H cases) lost hMSH2 with reduced hMSH6 expression in 15 and complete loss of hMSH6 expression in 10 cases. 66 cases $(55 \%)$ lost hMLH1, and 6 cases (5\%) lost hMSH6 only.

For cases with a proven loss of hMLH1 or hMSH2 expression, the most sensitive marker is BAT-26, which confirms the findings other research groups described above [49]. However, two cases with a loss of hMSH6 protein expression were MSS using BAT-26 alone whereas BAT25 showed instability in all samples with a loss of hMSH6. Thus we emphasize the necessity to use both BAT25 and BAT26 to increase sensitivity for overall MMR deficiency detection. The MSI-H cas- es that had lost hMSH2 and hMSH6 are most likely germline deficient in hMLH2 with a secondary somatic inactivation of hMSH6.

Interestingly, 12 cases with MSI-H showed no loss of protein expression in any of the three MMR-proteins studied. In 10 of these 12 cases both mononucleotide markers were unstable and at least one of the dinucleotide markers. One possible explanation is that the mutated protein is detected by the antibody even though it is not functional. Alternatively, loss of another MMR protein e.g. hPMS2 might have caused the instability. We saw a case with MSI-H that showed strong nuclear staining for hMSH2 and weak nuclear staining for hMLH1 and a frame shift mutation was found in exon 16 of the hMLH1 gene (T.B.E., R.F. unpublished observation).

The value of MSI-analysis for early identification of HNPCC patients in adenomas was studied in detail in our laboratory. Generally, HNPCC patients appear to develop intestinal polyps with the same frequency as the normal population, but they display a dramatic increase in speed of adenoma-to-carcinoma transition. Therefore, the identification of an MSI-H status in an adenoma as a pre-malignant lesion is of great importance for the management of patients. 
In the literature the detection rate for MSI-H in adenomas of HNPCC patients ranges widely from 57-90\% in different studies $[33,37,43,48]$. This might be due to a clinical rather than a molecular diagnosis of HNPCC, to different primer panels used, or to intralesional heterogeneity of the adenoma. In our series, we detected MSI-H in 17 of 22 adenomas of HNPCC patients with proven germline mutations using the consensus microsatellite panel on paraffin sections of the entire adenoma [G. Giuffre et al, manuscript in preparation]. Laser-microdissection revealed MSI-H in 3 additional adenomas because contaminating stromal or inflammatory cells could be further minimized. The classification as MSI-H in those three cases was further supported by immunohistochemistry which demonstrated loss of MSH2 (1 cases) and MLH1 (2 cases), respectively. Therefore, laser microdissection might reduce the number of false negatives (Fig. 7).

Based on our findings, we recommend using lasermicrodissection for MSI analysis. However, the limitations of laser-microdissection also need to be kept in mind. We aim to collect 100-300 cells for DNA extraction based on our validation studies $[29,30]$. We have seen two cases of a mucinous colon cancer where we initially missed MSI using 3 serial 5micron thick tissue sections of the formalin-fixed and paraffin-embedded tissue block. Even after laser microdissection of about $\sim 50$ tumour cells no clear MSI could be demonstrated in one of these cases. When the DNA preparation was repeated with about 200 tumour cells collected by extensive laser microdissection the carcinoma turned out to be unequivocally MSI-H (A.M. and J.R., manuscript in preparation). In our view this case led to a false negative result because the number of cells analyzed was too small. Alternatively, several areas of the tumor, possibly with different histologic features could be microdissected and subjected to microsatellite analysis. The important role of microdissection is to reduce the amount of contaminating cells that are not tumor cells and to avoid confounding results caused by intralesional heterogeneity.

The important role for the pathologist is to optimally guide the microdissection, to take into account histopathologic features and to integrate the findings with the clinical history. We also recommend that testing of other affected family members should be considered when the clinical suspicion for HNPCC is high and the laboratory findings are not conclusive.

\section{Conclusion}

In summary, identifying patients with HNPCC is still difficult in spite of the rapid progress that has been made in understanding MMR since the first MMR gene was cloned in 1993 [23]. HNPCC screening needs a wellequipped laboratory to perform meaningful microdissection and microsatellite analysis, immunohistochemistry and possibly mutation analysis as well as a pathologist, who integrates the results of the histopathologic and molecular analysis with the clinical findings and the family history. Close collaboration with clinicians and genetic counselors familiar with cancer predisposition syndromes is important. As the MMR status is getting more and more important in determining the treatment and management of patients [67], a screening program that is as sensitive and as specific as possible becomes extremely important. False-positive results of MMR deficiency may lead to over-treatment and unnecessary psychological stress for the patient as well as his/her family, and might prompt further unnecessary expensive and possibly invasive tests like mutation analysis or search for other HNPCC-related tumors. False-negative results, on the other hand, may exclude a patient from HNPCC surveillance, which could result in failure to detect new tumors at an early stage.

\section{References}

[1] L.A. Aaltonen, P. Peltomäki, F.S. Leach, P. Sistonen, L. Pylkkänen, J.P. Mecklin, H. Järvinen, S.M. Powell, J. Jen, S.R. Hamilton, G.M. Petersen, K.W. Kinzler and B. Vogelstein, Clues to the pathogenesis of familial colorectal-cancer, Science 260 (1993), 812-816.

[2] L.A. Aaltonen, P. Peltomaki, J.P. Mecklin, H. Jarvinen, J.R. Jass, J.S. Green, H.T. Lynch, P. Watson and G. Tallqvist, Replication errors in benign and malignant-tumors from hereditary nonpolyposis colorectal-cancer patients, Cancer Research $\mathbf{5 4}$ (1994), 1645-1648.

[3] Y. Akiyama, R. Iwanaga, T. Ishikawa, K. Sakamoto, N. Nishi, Z. Nihei, T. Iwama, K. Saitoh and Y. Yuasa, Mutations of the transforming growth factor-beta type II receptor gene are strongly related to sporadic proximal colon carcinomas with microsatellite instability, Cancer 78 (1996), 2478-2484.

[4] W.A. Albano and H.T. Lynch, Clinical management of hereditary colon cancer, in: Colon and Genetics, Van Nostrian Reinhold, P.M. Lynch and H.T. Lynch, eds, New York, 1985, pp. 99-110.

[5] J. Alexander, T. Watanabe, T.T. Wu, A. Rashid, S. Li and S.R. Hamilton, Histopathological identification of colon cancer with microsatellite instability, Am J Pathol 158 (2001), 527-535.

[6] K.G. Biden, L.A. Simms, M. Cummings, R. Buttenshaw, E. Schoch, J. Searle, G. Gobe, J.R. Jass, S.J. Meltzer, B.A. Leggett and J. Young, Expression of Bcl-2 protein is decreased in colorectal adenocarcinomas with microsatellite instability, Oncogene 18 (1999), 1245-1249. 
[7] T. Bocker, J. Diermann, W. Friedl, J. Gebert, E. Holinski Feder, J. Karner Hanusch, M. von Knebel Doeberitz, K. Koelble, G. Moeslein, H.K. Schackert, H.C. Wirtz, R. Fishel and J. Rüschoff, Microsatellite instability analysis: a multicenter study for reliability and quality control, Cancer Res $\mathbf{5 7}$ (1997), 4739-4743.

[8] T. Bocker, J. Schlegel, F. Kullmann, G. Stumm, H. Zirngibl, J.T. Epplen and J Ruschoff, Genomic instability in colorectal carcinomas: comparison of different evaluation methods and their biological significance, J Pathol 179 (1996), 15-19.

[9] C.R. Boland, J. Sato, K. Saito, J.M. Carethers, G. Marra, L. Laghi and D.P. Chauhan, Genetic instability and chromosomal aberrations in colorectal cancer: a review of the current models, Cancer Detect Prev 22 (1998), 377-382.

[10] C.R. Boland, S.N. Thibodeau, S.R. Hamilton, D. Sidransky, J.R. Eshlemann, R.W. Burt, S.J. Meltzer, M.A. RodriguezBias, R. Fodde, G.N. Ranzani and S. Srivastava, A National Cancer Institute workshop on microsatellite instability for cancer detection and familial predisposition: development of international criteria for the determination of microsatellite instability in colorectal cancer, Cancer Res 58 (1998), 52485257.

[11] P. Branch, D.C. Bicknell, A. Rowan, W.F. Bodmer and P. Karran, Immune surveillance in colorectal carcinoma, Nat Genet 9 (1995), 231-232.

[12] T.A. Brentnall, R. Chen, J.G. Lee, M.B. Kimmey, M.P. Bronner, R.C. Haggitt, K.V. Kowdley, L.M. Hecker and D.R. Byrd, Microsatellite instability and K-ras mutations associated with pancreatic adenocarcinoma and pancreatitis, Cancer Res $\mathbf{5 5}$ (1995), 4264-4267.

[13] C.E. Bronner, S.M. Baker, P.T. Morrison, G. Warren, L.G. Smith, M.K. Lescoe, M. Kane, C. Earabino, J. Lipford, A. Lindblom, P. Tannergård, R.J. Bollag, A.R. Godwin, D.C. Ward, M. Nordenskjøld, R. Fishel, R. Kolodner and R.M. Liskay, Mutation in the DNA mismatch repair gene homologue hMLH1 is associated with hereditary non-polyposis colon cancer, Nature 368 (1994), 258-261.

[14] B. Budowle, R. Chakraborty, A.M. Giusti, A.J. Eisenberg and R.C. Allen, Analysis of the VNTR locus D1S80 by the PCR followed by high-resolution PAGE, Am J Hum Genet 48 (1991), 137-144.

[15] G. Calin, V. Herlea, G. Barbanti-Brodano and M. Negrini, The coding region of the Bloom syndrome BLM gene and of the proto-oncogene is mutated in genetically unstable sporadic gastrointestinal tumors, Cancer Res 58 (1998), 3777-3781.

[16] G. Cancel, I. An-Gourfinkel, G. Stevanin, O. Didierjean, N. Abbas, E. Hirsch, Y. Agid and A. Brice, Somatic mosaicism of the CAG repeat expansion in spinocerebellar ataxia type 3/Machado-Joseph disease, Hum Mutat 11 (1998), 23-27.

[17] J.M. Cunningham, E.R. Christensen, D.J. Tester, C.Y. Kim, P.C. Roche, L.J. Burgart and S.N. Thibodeau, Hypermethylation of the hMLH1 Promoter in Colon Cancer with Microsatellite Instability, Cancer Res 58 (1998), 3455-3460.

[18] D.O. Mc Daniel, B. Keats, V.V. Vedanarayanan and S.H. Subramony, Sequence variation in GAA repeat expansions may cause different phenotype display in Friedreich"s ataxia, Mov Disord 16 (2001), 1153-1158.

[19] G. Deng, A. Chen, J. Hong, H.S. Chae and Y.S. Kim, Methylation of $\mathrm{CpG}$ in a small region of the hMLH1 promoter invariably correlates with the absence of gene expression, Cancer Res 59 (1999), 2029-2033.

[20] W. Dietmaier, S. Wallinger, T. Bocker, F. Kullmann, R. Fishel and J. Rüschoff, Diagnostic microsatellite instability: defini- tion and correlation with mismatch repair protein expression, Cancer Res 57 (1997), 4749-4756.

[21] W. Dietmaier and F. Hofstadter, Detection of microsatellite instability by real time PCR and hybridization probe melting point analysis, Lab Invest 81 (2001), 1453-1456.

[22] M.G. Dunlop, S.M. Farrington, A.D. Carothers, A.H. Wyllie, L. Sharp, J. Burn, B. Liu, K.W. Kinzler and B. Vogelstein, Cancer risk associated with germline DNA mismatch repair gene mutations, Hum Mol Genet 6 (1997), 105-110.

[23] R. Fishel, M.K. Lescoe, M.R.S. Rao, N.G. Copeland, N.A. Jenkins, J. Garber, M. Kane and R. Kolodner, The human mutator gene homolog MSH2 and its association with hereditary nonpolyposis colon cancer, Cell 75 (1993), 1027-1038.

[24] J.V. Frei, Hereditary nonpolyposis colorectal cancer (Lynch syndrome II). Diploid malignancies with prolonged survival, Cancer 69 (1992), 1108-1111.

[25] R. Gryfe, H. Kim, E.T. Hsieh, M.D. Aronson, E.J. Holowaty, S.B. Bull, M. Redston and S. Gallinger, Tumor microsatellite instability and clinical outcome in young patients with colorectal cancer, $N$ Engl J Med 342 (2000), 69-77.

[26] R. Gryfe and S. Gallinger, Microsatellite instability, mismatch repair deficiency, and colorectal cancer, Surgery 130 (2001), 17-20. G.

[27] Gyapay, F. Ginot, S. Nguyen, A. Vignal and J. Weissenbach, Genotyping Procedures in Linkage Mapping, Methods 9 (1996), 91-97.

[28] H.J. Han, A. Yanagisawa, Y. Kato, J.G. Park and Y. Nakamura, Genetic instability in pancreatic cancer and poorly differentiated type of gastric cancer, Cancer Res 53 (1993), 5087-5089.

[29] E. Heinmoller, W. Dietmaier, H. Zirngibl, P. Heinmoller, W. Scaringe, K.W. Jauch, F. Hofstadter and J. Ruschoff, Molecular analysis of microdissected tumors and preneoplastic intraductal lesions in pancreatic carcinoma, Am J Pathol 157 (2000), 83-92.

[30] E. Heinmoller, B. Renke, K. Beyser, W. Dietmaier, C. Langner and J. Ruschoff, Pitfalls in diagnostic molecular pathologysignificance of sampling error, Virchow's Arch 439 (2001), 504-511.

[31] J.G. Herman, A. Umar, K. Polyak, J.R. Graff, N. Ahuja, J.-P.J. Issa, S. Markowitz, J.K.V. Willson, S.R. Hamilton, K.W. Kinzler, M.F. Kane, R.D. Kolodner, B. Vogelstein, T.A. Kunkel and S.B. Baylin, Incidence and functional consequences of hMLH1 promoter hypermethylation in colorectal carcinoma, Proc Natl Acad Sci USA 95 (1998), 6870-6875.

[32] J. Huang, N. Papadopoulos, A.J. McKinley, S.M. Farrigton, L.J. Curtis, S. Zheng, J.K. Wilson, S.D. Markowitz, P. Morin, K.W. Kinzler, B. Vogelstein and M.G. Dunlop, APC mutations in colorectal tumors with mismatch repair deficiency, Proc Natl Acad Sci USA 20 (1996), 9049-9054.

[33] H. Iino, L. Simms, J. Young, J. Arnold, I.M. Winship, S.I. Webb, K.L. Furlong, B. Leggett and J.R. Jass, DNA microsatellite instability and mismatch repair protein loss in adenomas presenting in hereditary non-polyposis colorectal cancer, Gut 47 (2000), 37-42.

[34] Y. Ionov, M.A. Peinado, S. Malkhosyan, D. Shibata and M. Perucho, Ubiquitous somatic mutations in simple repeated sequences reveal a new mechanism for colonic carcinogenesis, Nature 363 (1993), 558-561.

[35] J.R. Jass and L.H. Sobin, Histologic typing of intestinal tumours, World Health Organisation International Classification of Tumours, Springer Verlag, 1989.

[36] J.R. Jass, K.A. Do, L.A. Simms, H. Iino, C. Wynter, S.P. Pillay, J. Searle, G. Radford-Smith, J. Young and B. Leggett, Mor- 
phology of sporadic colorectal cancer with DNA replication errors, Gut 42 (1998), 673-679.

[37] J.R Jass, Y. Ajioka, M. Radojkovic, L.J. Allison and M.R. Lane, Failure to detect colonic mucosal hyperproliferation in mutation positive members of a family with hereditary nonpolyposis colorectal cancer, Histopathology 30 (1997), 201207.

[38] J.R. Jass, hMLH1 and hMSH2 immunostaining in colorectal cancer, Gut 47 (2000), 315-316.

[39] N.G. Kim, Y.R. Choi, M.J. Baek, Y.H. Kim,H Kang, N.K. Kim and J.S. Min, Frameshift mutatons at coding mononucleotide repeats of the hRAD 50 gene in gastrointestinal carcinomas with microsatellite instability, Cancer Res 61 (2001), 36-38.

[40] R.D. Kolodner, J.D. Tytell, J.L. Schmeits, M.F. Kane, R.D. Gupta, J. Weger, S. Wahlberg, E.A. Fox, D. Peel, A. Ziogas, J.E. Garber, S. Syngal, H. Anton-Culver and F.P. Li, Germline msh6 mutations in colorectal cancer families, Cancer Res 59 (1999), 5068-5074.

[41] M. Kouri, A. Laasonen, J.P. Mecklin, H. Jarvinen, K. Franssila and S. Pyrhonen, Diploid predominance in hereditary nonpolyposis colorectal carcinoma evaluated by flow cytometry, Cancer 65 (1990), 1825-1829.

[42] E.J. Kremer, M. Pritchard, M. Lynch, S. Yu, K. Holman, E. Baker, S.T. Warren, D. Schlessinger, G.R. Sutherland and R.I. Richards, Mapping of DNA instability at the fragile $\mathrm{X}$ to a trinucleotide repeat sequence $\mathrm{p}(\mathrm{CCG}) \mathrm{n}$, Science 252 (1991), 1711-1714.

[43] S.J. Lanspa, H.T. Lynch, T.C. Smyrk, P. Strayhorn, P. Watson, J.F. Lynch, J.X. Jenkins and H.D. Appelman, Colorectal adenomas in the Lynch syndromes. Results of a colonoscopy screening program, Gastroenterology 98 (1990), 1117-1122.

[44] F.S. Leach, N.C. Nicolaides, N. Papadopoulos, B. Liu, J. Jen, R. Parsons, P. Peltomaki, P. Sistonen, L.A. Aaltonen, J.M. Trent, A. de la Chapelle, K.W. Kinzler and B. Vogelstein, Mutations of a mutS homolog in hereditary nonpolyposis colorectal cancer, Cell 75 (1993), 1215-1225.

[45] C. Lengauer, K.W. Kinzler and B. Vogelstein, Genetic instability in colorectal cancers, Nature 386 (1997), 623-627.

[46] B. Liu, S.M. Farrington, G.M. Petersen, S.R. Hamilton, R. Parsons, N. Papadopoulos, T. Fujiwara, J. Jen, K.W. Kinzler and B. Vogelstein, Genetic instability occurs in the majority of young-patients with colorectal-cancer, Nature Medicine 1 (1995), 348-352.

[47] L.A. Loeb, Mutator phenotype may be required for multistage carcinogenesis, Cancer Res 51 (1991), 3075-3079.

[48] A. Loukola, R. Salovaara, P. Kristo, A.L. Moisio, H. Kaariainen, H. Ahtola, M. Eskelinen, N. Harkonen, R. Julkunen, E. Kangas, S. Ojala, J. Tulikoura, E. Valkamo, H. Jarvinen, J.P. Mecklin, A. de la Chapelle and L.A. Aaltonen, Microsatellite instability in adenomas as a marker for hereditary nonpolyposis colorectal cancer, Am J Pathol 155 (1999), 1849-1853.

[49] A. Loukola, K. Eklin, P. Laiho, R. Salovaara, P. Kristo, H. Jarvinen, J.P. Mecklin, V. Launonen and L.A. Aaltonen, Microsatellite marker analysis in screening for hereditary nonpolyposis colorectal cancer (HNPCC), Cancer Res 61 (2001), 4545-4549.

[50] H.T. Lynch, J.F. Lynch, The Lynch syndromes, Curr Opin Oncol 5 (1993), 687-696.

[51] H.T. Lynch, T.C. Smyrk, P. Watson, S.J. Lanspa, J.F. Lynch, P.M. Lynch, R.J. Cavalieri and C.R. Boland, Genetics, natural history, tumor spectrum, and pathology of hereditary nonpolyposis colorectal cancer: an updated review, Gastroenterology 104 (1993), 1535-1549.
[52] M. Mahadevan, C. Tsilfidis, S. Sabourin, G. Shutler, C. Amemiya, G. Jausen, C. Neville, M. Narang and J. Barcelo, Myotonic dystrophy mutation: an unstable CTG repeat in the 3'untranslated region of the gene, Science 255 (1992), $1253-1255$.

[53] S. Markowitz, J. Wang, L. Myeroff, R. Parsons, L.Z. Sun, J. Lutterbaugh, R.S. Fan, E. Zborowska, K.W. Kinzler, B. Vogelstein, M. Brattain and J.K.V. Willson, Inactivation of the type II TGF b receptor in colon cancer cells with microsatellite instability, Science 268 (1995), 1336-1338.

[54] P. Modrich, DNA mismatch correction, Annu Rev Biochem 56 (1987), 435-466.

[55] P. Modrich, Mechanisms and biological effects of mismatch repair, Annu Rev Genet 25 (1991), 229-253.

[56] A. Müller, F. Alves, M. Breul and H. Becker, HNPCCassoziierte Magenkarzinome zeigen ein aggressiveres Wachstum bei orthotoper Transplantation in die Scid-Maus, Langenbecks Arch für Chirurgie Suppl (1998), 689-691.

[57] N.C. Nicolaides, N. Papadopoulos, B. Liu, Y.F. Wei, K.C. Carter, S.M. Ruben, C.A. Rosen, W.A. Haseltine, R.D. Fleischmann, C.M. Fraser, M.D. Adams, J.C. Venter, S.R. Hamilton, G.M. Petersen, A. de la Chapelle, B. Vogelstein and K.W. Kinzler, Mutations of two PMS homologues in hereditary nonpolyposis colon cancer, Nature 371 (1994), 75-80.

[58] N.C. Nicolaides, F. Palombo, K.W. Kinzler, B. Vogelstein and B. Jiricny, Molecular cloning of the N-terminus of GTBP, Genomics 31 (1996), 395-397.

[59] H.T. Orr, M. Chung, S. Banfi, Jr. T.J. Kwiatkoski, A. Servadio, A.L. Beaudet, A.E. Mc Call, L.A. Duvick L.P.W. Ranum and H.Y. Zoghbi, Expansion of an unstable trinucleotide CAG repeat in spino cerebellar ataxia type 1, Nat Genet 4 (1993), 221-226.

[60] N. Papadopoulos and A. Lindblom, Molecular basis of HNPCC: mutations of MMR genes, Hum Mutat 10 (1997), 89-99.

[61] N. Papadopoulos, N.C. Nicolaides, B. Liu, R. Parsons, C. Lengauer, F. Palombo, A. Darrigo, S. Markowitz, J.K.V. Willson, K.W. Kinzler, J. Jiricny and B. Vogelstein, Mutations of GTBP in genetically unstable cells, Science 268 (1995), 1915-1917.

[62] N. Papadopoulos, N.C. Nicolaides, Y.F. Wei, S.M. Ruben, K.C. Carter, C.A. Rosen, W.A. Haseltine, R.D. Fleischmann, C.M. Fraser, M.D. Adams, S.R. Hamilton, H.T. Lynch, P. Peltomäki, J.P. Mecklin, A. de la Chapelle, K.W. Kinzler and B. Vogelstein, Mutation of a mutL homolog in hereditary coloncancer, Science 263 (1994), 1625-1629.

[63] R. Parsons, G.M. Li, M.J. Longley, W.H. Fang, N. Papadopoulos, J. Jen, A. de la Chapelle, K.W. Kinzler, B. Vogelstein and P. Modrich, Hypermutability and mismatch repair deficiency in RER + tumor cells, Cell 75 (1993), 1227-1236.

[64] P. Peltomäki, R.A. Lothe, L.A. Aaltonen, L. Pylkkänen, R. Seruca, L. David, R. Holm, D. Ryberg, A. Haugen, A. Brøgger, A.L. Børresen, A. de la Chapelle and B. Vogelstein, Microsatellite instability is associated with tumors that characterize the hereditary non-polyposis colorectal carcinoma syndrome, Cancer Res 53 (1993), 5853-5855.

[65] M. Ponz de Leon, R. Sassatelli, P. Benatti and L. Roncucci, Identification of hereditary nonpolyposis colorectal cancer in the general population. The 6-year experience of a populationbased registry, Cancer 71 (1993), 3493-3501.

[66] N. Rampino, H. Yamamoto, Y. Ionov, Y. Li, H. Sawai, J.C. Reed and M. Perucho, Somatic frameshift mutations in the BAX gene in colon cancers of the microsatellite mutator phenotype, Science 275 (1997), 967-969. 
[67] C.M. Ribic, D.J. Sargent, M.J. Moore, S.N. Thibedau, A.J. French, R.M. Goldberg, S.R. Hamilton, P. Laurent-Puig, R. Gryfe, L.E. Shepherd, D. Tu, M. Redston and S. Gallinger, Tumor microsatellite-instability status as a predictor of benefit from flurouracil-based adjuvant chemotherapy for colon cancer, New Engl J Med 349 (2003), 247-257.

[68] J.I. Risinger, A. Berchuck, M.F. Kohler, P. Watson, H.T. Lynch and J. Boyd, Genetic instability of microsatellites in endometrial carcinoma, Cancer Res 53 (1993), 5100-5103.

[69] J.I. Risinger, A. Umar, J. Boyd, A. Berchuck, T.A. Kunkel and J.C. Barrett, Mutation of MSH3 in endometrial cancer and evidence for its functional role in heteroduplex repair, Nature Genetics 13 (1996), 102-105.

[70] M.A. Rodriguez-Bigas, C.R. Boland, S.R. Hamilton, D.E. Henson, J.R. Jass, P.M. Khan, H. Lynch, M. Perucho, T. Smyrk, L. Sobin and S. Srivastava, A National Cancer Institute workshop on hereditary nonpolyposis colorectal cancer syndrome: meeting highlights and Bethesda guidelines, $\mathrm{J} \mathrm{Natl}$ Cancer Inst 89 (1997), 1758-1762.

[71] J. Rüschoff, T. Bocker, J. Schlegel, G. Stumm and F. Hofstaedter, Microsatellite instability - new aspects in the carcinogenesis of colorectal carcinoma, Virchows Arch 426 (1995), $215-222$.

[72] J. Rüschoff, W. Dietmaier, J. Lüttges, G. Seitz, T. Bocker, H. Zirngibl, J. Schlegel, H.K. Schackert, K.W. Jauch and F. Hofstädter, Poorly differentiated colon adenocarcinoma, medullary type. Clinical, phenotypic, and molecular characteristics, Am J Pathol 150 (1997), 1815-1825.

[73] J. Rüschoff, S. Wallinger, W. Dietmaier, T. Bocker, G. Brockhoff, F. Hofstädter and R. Fishel, Aspirin suppresses the mutator phenotype associated with hereditary nonpolyposis colorectal cancer by genetic selection, Proc Natl Acad Sci USA 95 (1998), 11301-11306.

[74] J. Schlegel, T. Bocker, H. Zirngibl, F. Hofstadter and J. Ruschoff, Detection of microsatellite instability in human colorectal carcinomas using a non-radioactive PCR-based screening technique, Virchows Arch 426 (1995), 223-227.

[75] D. Shibata, M.A. Peinado, Y. Ionov, S. Malkhosyan and M. Perucho, Genomic instability in repeated seqeinces is an early somatic event in colorectal tumorigenesis that persists after transformation, Nat Genet 6 (1994), 273-281.

[76] S.B. Simpkins, T. Bocker, E.M. Swisher, D.G. Mutch, D.J. Gersell, A.J. Kovatich, J.P. Palazzo, R. Fishel and P.J. Goodfellow, MLH1 promoter methylation and gene silencing is the primary cause of microsatellite instability in sporadic endometrial cancers, Hum Mol Genet 8 (1999), 661-666.

[77] R.F. Souza, R. Appel, J. Yin, S. Wang, K.N. Smolinski, J.M. Abraham, T.T. Zou, Y.Q. Shi, J. Lei, J. Cottrell, K. Cymes, K. Biden, L. Simms, B. Leggett, P.M. Lynch, M. Frazier, S.M. Powell, N. Harpaz, H. Sugimura, J. Young and S.J. Meltzer, Microsatellite instability in the insulin-like growth factor II receptor gene in gastrointestinal tumours, Nat Genet 14 (1996), $255-257$.

[78] R.F.Souza, J. Yin, K.N. Smolinski, T.T. Zou, S. Wang, Y.Q. Shi, M.G. Rhyu, J. Cottrell, J.M. Abraham, K. Biden, L. Simms, B. Leggett, G.S. Bova, T. Frank, S.M. Powell, H. Sugimura, J. Young, N. Harpaz, K. Shimizu, N. Matsubara and S.J. Meltzer, Frequent mutation of the E2F-4 cell cycle gene in primary human gastrointestinal tumors, Cancer Res 57 (1997), 2350-2353.

[79] L. Spirio, G. Joslyn, L. Nelson, M. Leppert and R. White,
A CA repeat 30-70 KB downstream from the adenomatous polyposis coli (APC) gene, Nucleic Acids Res 19 (1991), 6348.

[80] R.E. Straub, M.C. Speer, Y. Luo, K. Rojas, J. Overhauser, J. Ott and T.C. Gilliam, A microsatellite genetic linkage map of human chromosome 18, Genomics 15 (1993), 48-56.

[81] D. Tautz, Notes on the definition and nomenclature of tandemly repetitive DNA sequences, Exs 67 (1993), 21-28.

[82] The Huntington Disease Collaborative Research Group. A novel gene containing a trinucleotide repeat that is expanded and unstable on Huntington's disease chromosomes, Cell $\mathbf{7 2}$ (1993), 371-383.

[83] S.N. Thibodeau, G. Bren and D. Schaid, Microsatellite instability in cancer of the proximal colon, Science 260 (1993), 816-819.

[84] S.N. Thibodeau, A.J. French, P.C. Roche, J.M. Cunningham, D.J. Tester, N.M. Lindor, G. Moslein, S.M. Baker, R.M. Liskay, L.J. Burgart, R. Honchel and K.C. Halling, Altered expression of hMSH2 and hMLH1 in tumors with microsatellite instability and genetic alterations in mismatch repair genes, Cancer Res 56 (1996), 4836-4840.

[85] H.F. Vasen, J.P. Mecklin, P.M. Khan and H.T. Lynch, The International Collaborative Group on Hereditary Non-Polyposis Colorectal Cancer (ICG-HNPCC), Dis Colon Rectum 34 (1991), 424-425.

[86] H.F. Vasen, R.B. van der Luijt, J.F. Slors, E. Buskens, P. de Ruiter, C.G. Baeten, W.R. Schouten, H.J. Oostvogel, J.H. Kuijpers, C.M. Tops and P. Meera Khan, Molecular genetic tests as a guide to surgical management of familial adenomatous polyposis, Lancet 348 (1996), 433-435.

[87] M.L. Veigl, L. Kasturi, J. Olechnowitz, A. Ma, J.D. Lutterbaugh, S. Periyasamy, G.M. Li, J. Drummond, P. Modrich, W.D. Sedwick and S.D. Markowitz, Biallelic inactivation of hMLH1 by epigenetic silencing, a novel mechanism causing human MSI cancers, Proc Natl Acad Sci 95 (1998), 86988702.

[88] T. Watanabe, T.T. Wu, P.J. Catalano, T. Ueki, R. Satriano, D.G. Haller, A.B. Benson and S.R. Hamilton, Molecular predictors of survival after adjuvant chemotherapy for colon cancer, $N$ Engl J Med 344 (2001), 1196-1206.

[89] J.L. Weber and P.E. May, Dinucleotide repeat polymorphism at the D10S89 locus, Nucleic Acids Res 18 (1990), 4637.

[90] J.L. Weber, A.E. Kwitek, P.E. May, M.R. Wallace, F.S. Collins and D.H. Ledbetter, Dinucleotide repeat polymorphisms at the D17S250 and D17S261 loci, Nucleic Acids Res 18 (1990), 4640.

[91] J. Weissenbach, G. Gyapay, C. Dib, A. Vignal, J. Morissette, P. Millasseau, G. Vaysseix and M. Lathrop, A second-generation linkage map of the human genome, Nature 359 (1992), 794 801.

[92] Y. Wu, M.J. Berends, R.G. Mensink, C. Kempinga, R.H. Sijmons, A.G. van der Zee, H. Hollema, J.H. Kleibeuker, C.H. Buys and R.M. Hofstra, Association of hereditary nonpolyposis colorectal cancer-related tumors displaying low microsatellite instability with MSH6 germline mutations, Am J Hum Genet 65 (1999), 1291-1298.

[93] Y. Wu, M.J. Berends, R.H. Sijmons, R.G. Mensink, E. Verlind, K.A. Kooi, T. Sluis, C. Kempinga, A.G. van der Zee, H. Hollema, C.H. Buys, J.H. Kleiber and R.M. Hofstra, A role for MLH3 in hereditary nonpolyposis colorectal cancer, Nat Genet 29 (2001), 137-138. 


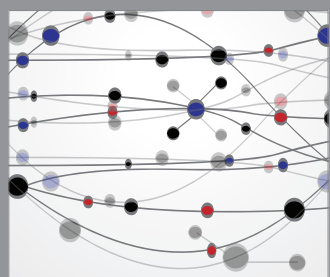

The Scientific World Journal
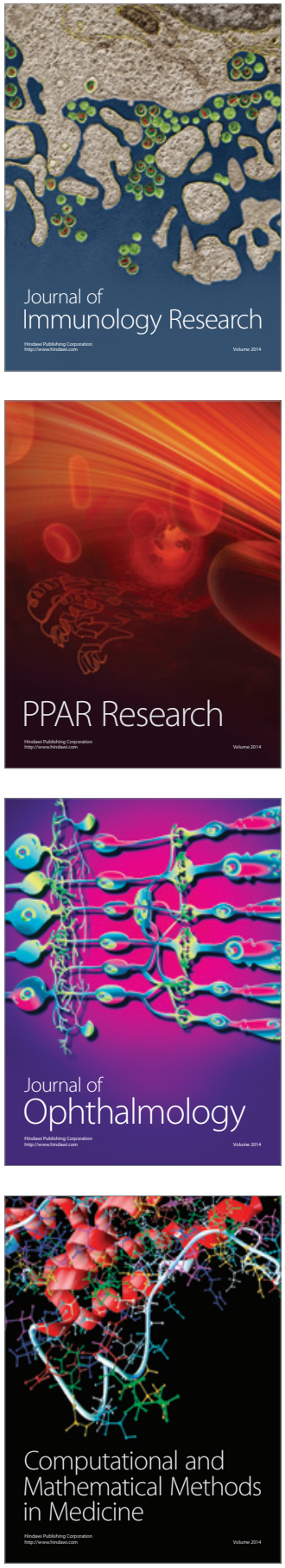

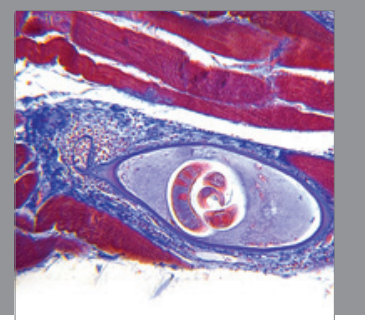

Gastroenterology

Research and Practice
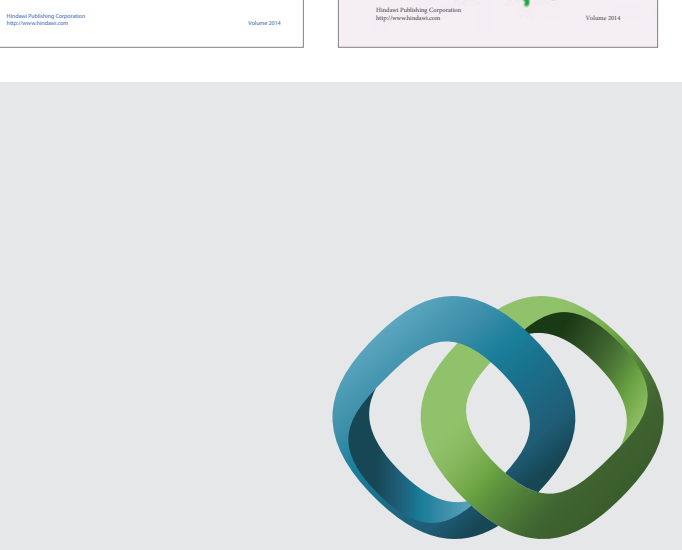

\section{Hindawi}

Submit your manuscripts at

http://www.hindawi.com
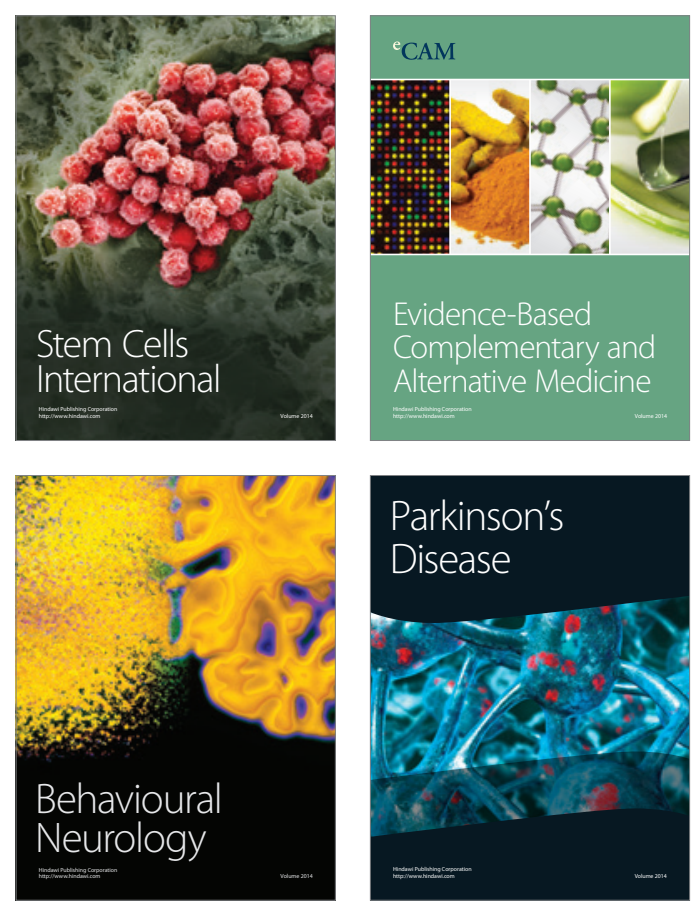

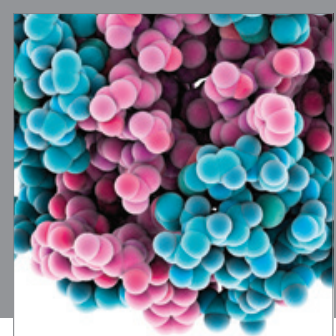

Journal of
Diabetes Research

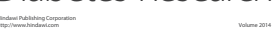

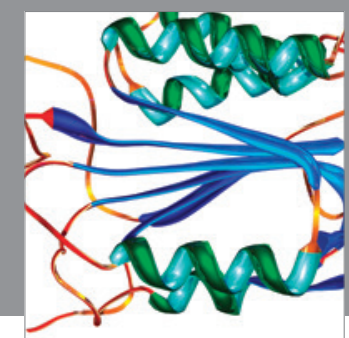

Disease Markers
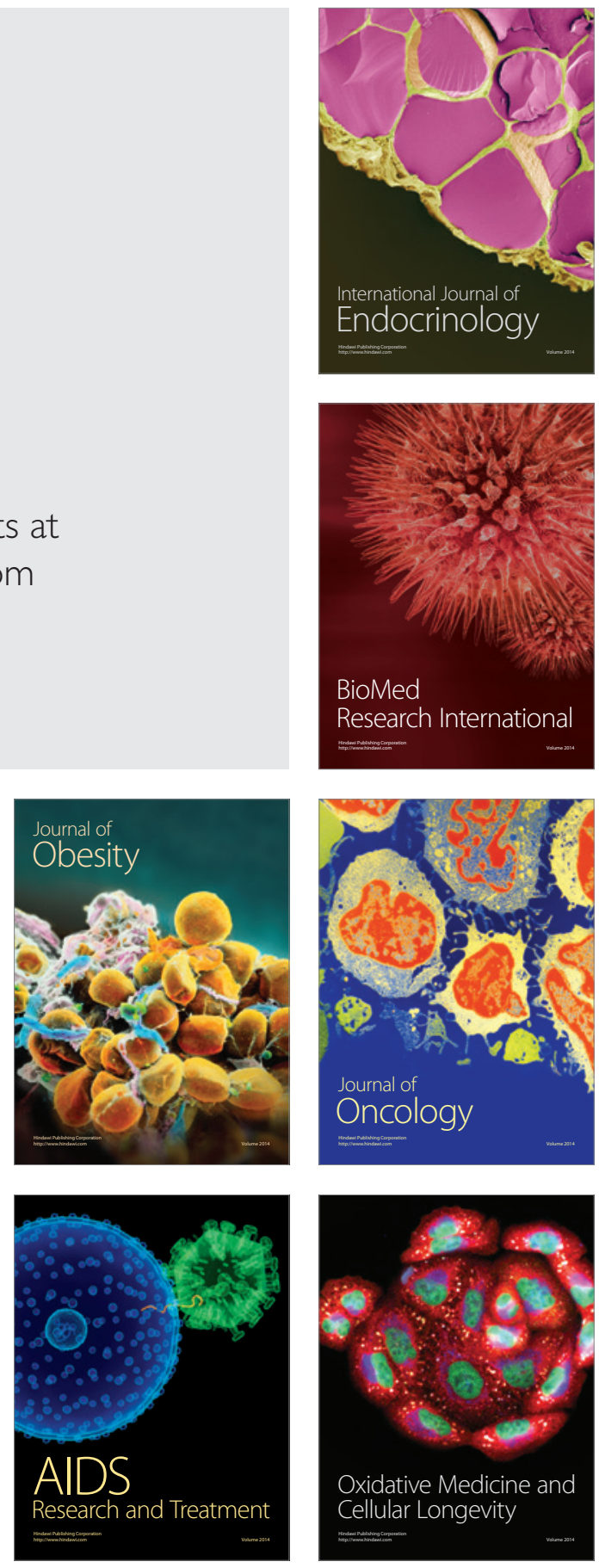